\title{
Grammatical Choice and Meaning in Media Discourse: The Spanish Periphrastic Passive
}

\author{
Miguel A. Aijón-Oliva \\ Departamento de Lengua Española, Universidad de Salamanca, Spain \\ Correspondence: Miguel A. Aijón-Oliva, Departamento de Lengua Española, Universidad de Salamanca. Plaza \\ de Anaya, 1.37008 Salamanca, Spain. E-mail: maaijon@usal.es
}

Received: August 2, 2013 Accepted: August 14, 2013 Available online: September 3, 2013

doi:10.11114/smc.v1i2.191 URL: http://dx.doi.org/10.11114/smc.v1i2.191

\begin{abstract}
This paper investigates the use of Spanish periphrastic passive constructions in a corpus of written-press and radio discourse from a Peninsular town. Their statistical patterning and their contextual effects are analyzed across a variety of textual genres and speaker socioprofessional groups within the domain of the media. The construction turns out to be more frequent as discourse approaches the prototype of written, informational communication, such as in press news items and radio news reports, as well as in the speech of journalists and broadcasters. A relationship is then hypothesized between such distribution and the inherent discursive meaning of the passive. Its basic motivation appears to be the enhancement of the salience of a semantic patient by placing it in the position of the clause subject, which is parallel to a notional blurring of the agent. This largely explains the usual occurrence of passive constructions across informational discourse dealing with external third-person referents, as well as their association with the speech of the socioprofessional groups that most often produce such kind of discourse. It is concluded that the patterns of variation found among social groups and situations are undetachable from the discursive meanings generated by linguistic choices.
\end{abstract}

Key words: passive, grammatical choice, written press, radio, sociolinguistic style

\section{Introduction: The Passive as a Communicative Choice}

\subsection{The Variation between Active and Passive Constructions}

The choice between Spanish active and periphrastic passive constructions with the verb ser 'be' has been addressed in different descriptive, functional and correlational studies (Morales, 1992; Casanovas Catalá, 1999; Mendikoetxea, 1999a; López Morales, 2000, 2006; Fernández, 2004, 2007; Vázquez \& Hernández 2010; Noh, 2011, among others), just as in other languages having similar structures. The phenomenon seems to readily lend itself to conceptualization as a grammatical variable, involving two syntactic structures that may be used to represent the same real-world event (examples 1a, b).

(1a) El Parlamento aprobó la ley 'The Parliament passed the law'

(1b) La ley fue aprobada por el Parlamento 'The law was passed by the Parliament'

Linguistic variants are usually conceived as synonymous options whose choice is statistically conditioned by certain independent—internal and often also external—factors (Chambers, 2003: §1.2). However, there are quite obvious differences between (1a) and (1b) as regards the perspective from which the event is watched. This is reflected in the allocation of grammatical functions-particularly the subject and its agreement with the verb - and the syntactic order. Given the essentially iconic nature of grammar posited by different functional and cognitive models (e.g. Langacker, 1991, 2009; Goldberg, 1995; Givón, 2001; García, 2009), it makes little sense to assume that two grammatical structures like these can mean the same, or that their meanings can be contextually neutralized (Sankoff, 1988: 153-154). The apparent descriptive equivalence- the fact that both constructions can describe the same event-does not rule out the possibility of variation at other levels of meaning.

Moreover, when dealing with grammatical phenomena it is often impossible to identify all possible contexts of variation: in our case, active sentences are the rule in Spanish and passive ones the exception, and it seems futile 
to discuss whether an active clause could have been formulated as passive. Also, even if this were feasible, it would mean neglecting the fact that the speaker probably had some reason to say what he/she chose to say. ${ }^{\mathrm{i}}$ The ser passive often sounds unnatural when the event described is not a prototypically transitive one, that is, when it is not assimilable to the canonical event model (cf. Langacker, 1991: 285-286) involving a current of energy from an agent to a patient, which causes some alteration in the latter. Given that in the prototypical declarative clause the agent is syntactically encoded as subject and the patient as object, the passive could be seen as representing the reverse configuration. Example (2b) below is doubtful, whereas (2c) is ungrammatical. This is clearly connected to the types of events they describe - psychological and emotional processes - as well as to imperfective verbal aspect; they are viewed as ongoing situations rather than as one-time actions.

(2a) Juan compró el libro / El libro fue comprado por Juan

'John bought the book / The book was bought by John'

(2b) Juan amaba la poesía / ?La poesía era amada por Juan

'John loved poetry / Poetry was loved by John'

(2c) Juan sabe inglés / *nglés es sabido por Juan

'John speaks (lit. knows) English / English is known by John'

In sum, it is of little use to hypothesize what a speaker could have said in a given situation, but did not actually say (cf. Preston, 2001: 300-301). ii A much more comprehensive notion of linguistic choice is needed. Choice is not, as generally assumed by structural and variationist approaches, the mere process of selection among a limited number of formal alternatives. It should rather be seen as the human potential to creatively construct meanings within communicative contexts. It is difficult-and probably unnecessary - to ascertain how many options a speaker had at his/her disposal; any form actually used has some meaning in itself and not just from comparison with other possible ones.

Consequently, differences in meaning and function, far from hampering empirical research on formal alternation — as has often been assumed since Lavandera's (1978) early claims—, are exactly what justifies the existence of variation and might help reach a theoretical explanation for it (Aijón-Oliva, 2006: ch. 10; Serrano \& Aijón-Oliva, 2011). In the present case, it seems that the basic function of passive constructions is to turn a semantic patient into the discursive and perceptual protagonist, or the main perspective from which the event is watched (cf. Givón, 2001: 180; Fernández, 2004), as will be further discussed in Section 4.

\subsection{The Sociostylistic Side of the Passive}

Variation is, above all, a matter of communicative choice. Linguistic choices construct meanings in context, and in doing so they formalize different perceptions of the self, of others and of reality altogether. This all makes it possible for such choices to be used as stylistic tools, understanding 'style' as the construction of personal and social identities in communicative contexts (Coupland, 2007; Auer ed., 2007; Eckert, 2008; Aijón-Oliva \& Serrano, 2012).

It also follows that social groups and communicative situations should not only be differentiated according to the relative frequency with which they choose particular forms, but also to the relative preference for the meanings these convey. In fact, the existence of social and situational conditionings on the use of the Spanish ser passive is quite evident. Most native speakers would intuitively characterize the construction as far more typical of written language or of highly pre-planned discourse than of everyday spontaneous conversation (López Morales, 2006). Besides, language prescriptionists suggest that passive constructions are scarcely natural in Spanish, their use being most typical of journalists, scientists and any authors intending to enhance the tone of their writing and promoting affectation over naturalness (Seco, 1996: 162-163; Rodríguez, 2001; Grijelmo, 2006: 216). This is why, despite intuitive characterizations of the passive as a 'formal' and 'literate' construction, texts on linguistic correctness often caution against its use and especially its abuse. ${ }^{\text {iii }}$

The present study will address the use of the Spanish passive in media discourse. The construction is regarded as particularly frequent in this communicative domain, which is sometimes explained as an effect of the direct translation of English reports (Casado Velarde, 1995: 159; Real Academia Española, 2009: §41.2), where be passives are fairly usual and contextually versatile. But, as will be discussed later, a tendency could also be hypothesized on the part of journalists and broadcasters to use expressive resources like the passive as characterizing features of their communicative styles.

\subsection{Research Questions}

First, we will investigate whether prescriptive judgments about the Spanish ser passive are matched by its 
variability according to textual genres and speaker socioprofessional identities. A quantitative analysis will be carried out on the materials provided by a corpus of mass-media - radio and written press-discourse. The goal is to answer the following questions:

- Is the ser passive more frequent in particular types of discourse across the domain of media communication, such as written and highly pre-planned ones?

- Can the construction be considered a characteristic feature of the speech of media professionals, or is it used with similar frequencies by all speakers/writers taking part in media interactions?

However, if we assume that - as pointed out in 1.1 - the choice of the passive is not just a formal phenomenon, but a meaningful and functional one as well, the analysis must go beyond the description of its situational and social patterning. It will also be necessary to address other, more complex questions:

- What particular meaning is expressed through the ser passive which is not conveyed —or at least not to the same extent - by active clauses and by other related constructions?

- Is there any relationship between such a meaning and the situational and social distribution of the passive construction? In other words, why should certain speaker groups and communicative situations favor not just the choice of some constructions over others, but also of the meanings they express?

As will be seen, the answers to these questions probably lie in a complex combination of factors, but their consideration is necessary in order to progress towards an explanatory view of linguistic choice in context.

\section{Corpus and Methodology}

The analysis will be based on the Corpus de Lenguaje de los Medios de Comunicación de Salamanca (MEDIASA), which comprises a total 302577 words, evenly divided between a radio subcorpus and a written-press one. All texts were collected from the main radio stations and newspapers of the Spanish Peninsular town of Salamanca during the years 2003 and 2004. ${ }^{\text {iv }}$ The texts are classified according to the textual genre they primarily belong to; speakers and writers are also characterized by some basic socioprofessional identities that will be reviewed below. Variation according to these external factors and some of its contextual projections will be the focus of the subsequent analysis.

The size and internal structure of the corpus have been designed to facilitate the combination of quantitative and qualitative approaches in the study of linguistic variation and choice. Despite being obviously small, it is expected to provide sufficient amounts of morphosyntactic tokens and thus allow for fairly reliable statistical calculations; but, at the same time, its reduced extension should make it possible to observe and discuss the particular circumstances and contextual motivations for each of those tokens. The corpus was collected in the same community where the author resides and after extensive preliminary observation within the specific domain of local mass-media communication. This complies with the growing need to enrich the study of linguistic variation with detailed ethnographic and interactional research (Bucholtz \& Hall, 2005; Eckert, 2008). Of course, studies on other communities and dialectal varieties should be made in order to replicate the findings of the present one.

As for the linguistic side of the analysis, it must be pointed out that the meaning of passive constructions has seldom been described in itself and without reference to that of active ones (Gries \& Stefanowitsch, 2006: 108); a broader, less structural conception of linguistic variants is needed in order to achieve theoretical adequacy in the analysis of linguistic choice. This is why, instead of measuring the rates of passive constructions against those of their alleged active counterparts, the overall frequencies of the former per 10000 text words will be calculated. ${ }^{\mathrm{V}}$ This will provide an objective basis for comparison among social groups and communicative situations (see Section 3). The statistical significance of the results will be assessed through the Kruskal-Wallis $H$ test. This is a non-parametric alternative to the analysis of variance, and has been chosen due to its higher reliability when the distribution of the data cannot be assumed to be strictly normal. ${ }^{\mathrm{vi}}$

However, in this study quantification will be handled as basically a methodological aid to a kind of analysis whose aim is to transcend statistical considerations and approach the meaningful core of morphosyntactic choice. The main goal is to determine whether the basic functions of a grammatical construction are related to its quantitative distribution and its qualitative usage across social and situational contexts.

\section{The Situational and Social Variation of the Periphrastic Passive}

Altogether, 186 items of ser passive clauses were found across the corpus. It can be inferred that - contrary to the usual intuition - the structure is not very frequent in mass-media discourse, its overall rate in the corpus being of just 6.1 cases per 10000 words. However, as will be shown, the figure rises notably when only the most 
prototypical instances of media discourse, particularly written news items and radio news reports, are taken into account. Let us now examine frequential variation across textual genres and social groups.

\subsection{Textual Genres}

The corpus under study comprises five written-press genres-news items, stories, opinion pieces, letters to the editor, interviews - and five radio ones - commercial stretches, news reports, sport programs, music programs, talk magazines. ${ }^{\text {vii }}$ Genres differ according to several functional and discursive dimensions (Biber, 1988; Biber \& Conrad, 2009), such as their placing along the orality-literacy continuum, their degree of pre-planning, their orientation towards informational vs. interactional communication, or their preference for formal/standard vs. informal/vernacular linguistic variants. These aspects are likely to result in different rates of ser passives.

Table 1. Textual genres and frequency of passive clauses

\begin{tabular}{lccc}
\hline Genre & Word count & Passive clauses & $\begin{array}{c}\text { Frequency per } \\
\text { 10 000 words }\end{array}$ \\
\hline News items & 59651 & 78 & 13.1 \\
Stories & 30314 & 20 & 6.6 \\
Opinion pieces & 30128 & 22 & 7.3 \\
Letters to the editor & 15201 & 13 & 8.6 \\
Interviews & 15288 & 5 & 3.3 \\
\hline Written-press total & 150582 & 138 & 9.2 \\
\hline Commercial stretches & 15230 & 2 & 1.3 \\
News reports & 18155 & 18 & 9.9 \\
Sport programs & 35226 & 5 & 1.4 \\
Music programs & 20901 & 6 & 2.9 \\
Talk magazines & 62483 & 17 & 2.7 \\
\hline Radio total & 151995 & 48 & 3.2 \\
\hline Kruskal-Wallis $H$ test: $\mathrm{H}=46.389 ;$ degrees of freedom: $9 ; \mathrm{p}<0.001$ & \\
\hline
\end{tabular}

Table 1 shows its frequency in each genre, as well as the global results for the written-press and radio subcorpora. The differences according to genres can be considered statistically significant at $p<0.001$. Notably, 138 (74.2\%) of the items appear in the written-press section of the corpus, both sections being of a practically equal size. In general terms, it is confirmed that passive clauses are rarer the closer a genre comes to the pole of orality (see also Fernández, 2007). All radio genres, with the exception of news reports - which are based on texts written to be read aloud-have remarkably low frequencies. Also, 4 out of 6 items in music programs appear across the reading of previously scripted stretches and not in the more typical 'conversational' speech of broadcasters. Speakers may even seem uncomfortable when using the construction without some previous formal reflection, as shown by occasional strange or awkward solutions like es cantado 'is sung' in example (3):

(3) Y: bueno / pues: e: así se graba: / este disco el disco en el que: bueno / Sabina: es: e / bendito / y es cantado / por: / todas las mujeres "Sabina entre todas las mujeres" es el título del álbum [Cadena 100, 09/23/03, 16:50]

'And, well, this is how they recorded this album, an album in which Sabina is blessed and is sung by all these women. "Sabina among women" is the title of the album.'

On the other hand, written genres show rather heterogeneous results, from 3.3 in interviews to 13.1 in news items. The low frequency in the former one-which mainly comprises transcriptions of previously recorded oral interactions - would again point to a relationship between the passive and written discourse. However, another functional continuum may also be relevant here: informational vs. interactional orientation (Biber, 1988: ch. 6). Certain genres are primarily based on the transmission of information or, more generally, on the execution of transactional activities; in others, personal involvement and the development of interpersonal relationships prevail. The prototype of informational genre in the written corpus is that of news items. Passives in such texts comply with the functional demands of informational communication: an entity first introduced in discourse as a syntactic object later rises to the position of preverbal subject (examples 4 and 5).

(4) Los responsables de la base aérea de Matacán han seleccionado a un grupo de 286 escolares de varios centros de Primaria y Secundaria de la provincia para que asistan a los actos de inauguración del parque "Eco Matacán" [...] Los niños han sido seleccionados a partir de la convocatoria de un concurso de 
dibujo, poesía y prosa. [La Gaceta, 1/31/04, p. 18]

'The managers of the Matacán air base have selected 286 students from several primary and secondary schools of the province as attendees to the acts of inauguration of the "Eco Matacán" theme park. The kids have been selected through a drawing, poetry and composition contest.'

(5) Julián Lanzarote ha preferido continuar depositando el peso del partido en personas jóvenes [...] Recupera también a Luis Heredero como secretario de Formación, Estudios y Programas y a Fernando Rodríguez como responsable de Comunicación. Los dos fueron sacrificados hace cuatro años en aras de la renovación. [La Gaceta, 12/20/2004, p. 7]

'J.L. has opted to pursue his policy of bestowing the responsibility of the party on young people... He is also bringing L.H. back as Secretary for Training, Studies and Programs, as well as F.R. for Communication. Both had been sacrificed four years ago for the sake of renovation.'

This could also explain the fact that opinion pieces and letters to the editor, both being argumentative-persuasive genres - thus generally intermediate on the information-interaction scale-, also obtain intermediate values: 7.3 and 8.6 respectively. As for the radio corpus, it should be easy to relate the 9.9 index of news reports to their strong informational orientation.

Apparently, the only problem for this explanation lies in written stories and their 6.6 index. This genre has many similarities to that of news items, both being composed of mainly informational texts authored by journalists. However, their index of passives is lower than could have been expected, even falling short of those of opinion pieces and letters. This a priori contradictory finding will be adequately explained when the discursive meaning of the passive construction and the correlations observed are jointly discussed in Section 4.

The main conclusion to be drawn from the situational analysis is that the Spanish ser passive is more frequent in scripted, informational textual genres. The prototype of all such features in media communication is written news items, and to a lesser extent radio news reports. It is thus hardly surprising for the passive to have become something of a characterizing feature of media discourse, which is most readily identified with information about specific events. However, it is also necessary to investigate whether the situational patterning of this construction interacts with speakers' social features, and thus whether it may characterize not just types of situation, but also ways of self-presentation.

\subsection{Socioprofessional Identities}

In 1.3, the question was raised whether the ser passive might be considered characteristic of the speech of professional communicators, or else its apparent profusion in media language might be a mere effect of its perception as a highly formal construction, especially appropriate for public situations. The latter hypothesis would be supported by the fact that it also seems to be comparatively frequent in domains such as technical, scientific and medical research (Oliver del Olmo, 2004: 172ff; Salazar et al., 2013) as well as administration and law (Vilches \& Sarmiento, 2011: 99-100). Therefore it could be useful to check whether different groups of people participating in media communication have unequal frequencies of the passive. The method employed to distinguish socioprofessional sectors in the corpus was an observational one, based on the ways speakers tend to present themselves and be presented by others in media communication - that is, the social and professional identities they display and the communicative rights and duties attached to them. ${ }^{\text {viii }}$ Four groups were isolated:

(a) Journalists and broadcasters. They generally hold the dominant position in media discourse and can determine the extent to which other groups are allowed to participate. However, their power is countered by the social exposure inherent to their job - they work in front of a presumably large, heterogeneous and mostly unknown audience that will judge their professional performance. This is likely to be reflected in their linguistic usage, with a preference for standard forms, or in any case for those associated with social prestige and power.

(b) Public figures. This second group is a more heterogeneous one, comprising speakers who are not media professionals, but are invited to participate due to their social prominence. Among them are intellectuals contributing to newspapers and radio stations, interviewees (artists, sportspeople, etc.), advertisers, representatives for companies and associations, etc. Just like journalists, they are often guided by the purpose of displaying a self-image of professionalism; however, they also tend to enjoy a higher degree of stylistic freedom.

(c) Politicians. They could obviously have been included in the previous group; the decision to detach them from it is based on the peculiarities of their interactional behavior, characterized by an explicit and commonly recognized orientation towards argumentation and persuasion (Blas Arroyo, 2011: 58-60). 
They tend to be highly aware of the social consideration of linguistic traits and see linguistic usage as a powerful tool for achieving political ends.

(d) Private individuals. Finally, these are people whose participation in media interactions is circumstantial: writers of letters to the editor, phone callers to citizen-participation sections in radio shows, passers-by being surveyed by reporters, etc. Their occupations and social ascriptions are a priori not publicly relevant, and sometimes not even their names are mentioned.

Table 2. Socioprofessional identities and frequency of passive clauses

\begin{tabular}{lccc}
\hline Socioprofessional group & Word count & Passive clauses & $\begin{array}{c}\text { Frequency per } \\
\text { 10 000 words }\end{array}$ \\
\hline Journalists and broadc. & 182774 & 139 & 7.6 \\
Public figures & 69380 & 27 & 3.9 \\
Politicians & 23839 & 13 & 5.5 \\
Private individuals & 26584 & 7 & 2.6 \\
\hline Kruskal-Wallis $H$ test: $\mathrm{H}=17.387 ;$ degrees of freedom: $3 ; \mathrm{p}<0.001$ & \\
\hline
\end{tabular}

Table 2 shows the frequencies of passive clauses for each of these groups as well as the statistical significance of the results. 139 (74.7\%) of the 186 passive clauses have been produced by journalists and broadcasters; however, it must be taken into account that more than half of the total words in the corpus correspond to them, which again shows the necessity of normalized frequencies for reliable comparison. This group turns out to have a rate of 7.6 passive clauses per 10000 words, a figure still clearly exceeding those of the others. It may also be worth pointing out that the local scope of the texts under analysis makes it difficult to attribute their use of passive clauses to translation from English news reports, which has often been adduced as one of the main factors promoting the use of the construction (see 1.2 above).

Even so, it is clear that the results of socioprofessional groups are difficult to detach from those of textual genres. The most informationally-oriented genres, such as news items - which, as we have seen, have the highest frequency of passive structures - are practically monopolized by journalists; in turn, private individuals usually participate in more interactional contexts. As explained by Finegan and Biber (2001) through their register axiom, the kinds of social situations in which people tend to participate are partly conditioned by their own social insertion, and will interact with their particular ways of speaking. ${ }^{\text {ix }}$ The important point to be made here is that journalists, through their high rates of passive constructions, are not just obeying the functional demands of certain genres, but at the same time are probably displaying the kind of socioprofessional identity they consider most appropriate for the fulfillment of their duties.

This can also be observed in the case of politicians, whose 5.5 index exceeds that of the rest of public figures. As remarked earlier, passives are not rare in argumentative discourse, such as is found in opinion pieces and letters to the editor. The use of the construction in the speech of politicians seems to emphasize assertiveness with the aim of persuading the audience. Consider the following two examples:

(6) nosotros le exigimos una cosa / y es que si tiene delegaciones / haga como el resto de los concejales delegados: / que: trabaje a pie de obra todos los días / que vaya cada semana a las comisiones correspondientes / que pueda ser controlado por los concejales de la oposición: / que representamos a m:uchos miles de salmantinos [Cadena SER, 06/18/03, 14:20]

'We want to demand something from him. He should do the same as any other town councilor-work readily everyday, attend the weekly committee meetings and let himself be monitored by us, the councilors in the opposition, since we represent thousands of Salamanca citizens.'

(7) el Archivo se consiguió mediante las almas [sic] / la di- / la unidad del Archivo no puede estar basada / en: / ell- en: / papeles / incautados / por las armas y: mediante fusilamientos / no puede:- / no puede ser amparada por eso [Punto Radio, 12/28/04, 12:55]

'The [Civil War] Archives were gathered through the use of weapons. Their integrity cannot be protected insofar as it results from the confiscation of documents by means of weapons and by the shooting of people.'

On the other hand, the low index for private individuals (2.6) might be indicative of the social perception of the passive as most adequate for public communicative situations, which according to Finegan and Biber (2001: 262) 
would result in higher frequencies and a better command of the resource for the social groups most accustomed to such situations. Moreover, it must be pointed out that all 7 items from this group were collected within a single discourse genre, namely letters to the editor. These are strongly argumentative texts in which the writer, expecting his/her contribution to be published in the journal, often seeks to perform a linguistic style that will be perceived as correct and socially elevated (example 8).

(8) Me parece un buen acto de solidaridad ir quitando poco a poco las barreras arquitectónicas para que invidentes y personas con minusvalías físicas o avanzada edad puedan circular con menos problemas. Una prueba de ello es la nueva glorieta de El Rollo y sus pasos de peatones, en la que todos sus bordillos han sido rebajados. [El Adelanto, 07/29/04, p. 6]

'I believe it is a humanitarian act to progressively remove architectural obstacles, so that blind and other physically handicapped people, as well as the elderly, will be able to walk at ease. A case in point is the new traffic circle in El Rollo and its pedestrian crossings, where all sidewalk curbs have been lowered.'

\subsection{The Passive as a Stylistic Choice}

All this suggests that the passive can in fact be viewed as a resource of sociolinguistic style, that is, as a formal-meaningful choice that can help the speaker shape a particular image of him/herself within some communicative situation (cf. Serrano \& Aijón-Oliva, 2011: 144-146). By way of syntactic choice, meanings are constructed at the descriptive level alongside the discursive and social-situational ones. It also becomes obvious that detaching the 'functional' from the 'social' or 'dialectal' facet of linguistic variation (Biber \& Conrad, 2009: $12 \mathrm{ff}$ ) is feasible only at a rather abstract level.

The examination of the context is indispensable to understand the stylistic meaning of some formal choice. In fact, the usual association of passive structures with formal expository discourse makes it possible to use them with different purposes - e.g. humorous, confrontational, puzzling — in other kinds of discourse. In the following excerpt we can observe the passivization of the intransitive verb dimitir 'resign' with a mocking intention:

(9) la Sra. Juez viene dando sobradas muestras de que el cargo le sobrepasa y le hace un flaco favor a sus compañeros de Consistorio y a la ciudad en general, pues vaya imagen de seriedad que debemos dar de cara al exterior. Le sugiero al alcalde que la citada Sra. sea “dimitida” ya. [La Gaceta, 01/29/04, p. 6]

'Mrs Juez has demonstrated only too well that she feels overwhelmed by her post and is rendering a poor service to her collaborators at the town council and to the town at large. What an image of seriousness we must be sending outwards! May I suggest to the Mayor that this lady be resigned right away.'

Even if ser passives prove to be especially frequent in the speech and writing of journalists, most people taking part in media communication are seemingly aware of their possibilities as stylistic traits, which are hard to separate from their association with certain communicative situations and genres. Within such a scenario, the passive would be just one among a wide array of linguistic choices contributing to the rise and evolution of communicative styles in social interaction. In the following discussion we will try to answer our main research questions: what the meaning of the periphrastic passive actually is, and whether and to what extent its extralinguistic distributional patterns, as well as its contextual projections, are connected to this meaning.

\section{Discussion: the Construction of Meaning through Formal Choice}

\subsection{The Discursive Meaning of the Passive}

As already exposed, the passive is usually seen as a reversal of the prototypical syntactic-semantic construction where a subject-agent performs an action on an object-patient. In passive clauses the latter takes up the syntactic place of the former, thus establishing agreement with the verb. In functional-cognitive terms, this means turning the object into the primary viewpoint from which the event is watched and thus causing a rise in its salience (Croft \& Cruse, 2004: 46-50). The salience of a referent in a context tends to be inversely proportional to the informativeness it bears, that is, its degree of newness or unexpectedness (Lambrecht, 1994: 273; Gundel \& Fretheim, 2009). In this sense, the passive is a resource for the thematization of the patient, which turns into already given or presupposed information. Conversely, the agent—if expressed at all—will tend to be presented as new information and will usually be placed to the right of the clause, in the form of a prepositional phrase. Already-known elements tend to appear in the clause-initial position in most languages (Fried, 2009: 292), even if this tendency can of course be contextually altered. Examples (10a) and (10b) show a typical active-passive pairing. 
(10a)

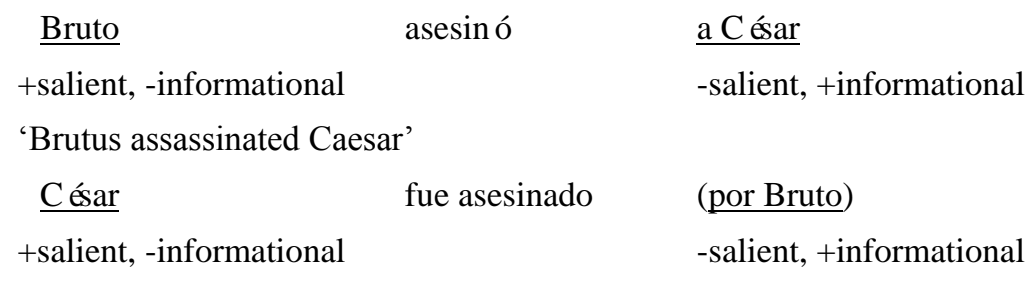

'Caesar was assassinated (by Brutus)'

Table 3. Position of the subject in relation to the verb in passive clauses

\begin{tabular}{lcc}
\hline Subject position & Number of passive clauses & $\%$ \\
\hline Preverbal or in previous clauses & 130 & 69.9 \\
Relative head & 46 & 24.7 \\
Postverbal & 10 & 5.4 \\
\hline Total & 186 & 100 \\
\hline
\end{tabular}

As can be seen in Table 3, 130 out of 186 items in the corpus (69.9\%) have the subject preposed to the verb. In fact, the former is often left unexpressed because it has already been formulated in previous clauses; in Spanish, subject omission indexes higher contextual salience of its referent (Serrano \& Aijón-Oliva, 2011: 147ff). If we add another 46 items in which the subject is formulated as the head of a relative clause, it turns out that only in 10 passive clauses $(5.4 \%)$ is the subject formulated after the verb.

Subject postposition is therefore rather atypical in this context. Textual progression generally allows for a referent initially encoded as an object to become the preposed passive subject, in parallel with an increase in its salience. In (11), we first find a passive subject-someone - that is subsequently abandoned; the direct object an obligation then becomes the main interest of discourse and turns into a new passive subject within a relative clause.

(11) Hasta hace muy poco tiempo, cuando una persona era condenada por un delito generalmente la pena de cárcel llevaba unida una indemnización a las víctimas de sus acciones que rara vez era satisfecha. [ La Gaceta, 12/22/03, p. 15]

'Until very recently, when someone was convicted for a crime, prison sentences used to include an obligation to compensate the victims that was seldom fulfilled.'

At this point it is necessary to mention a related construction: the so-called 'reflexive passive', whereby the third-person reflexive clitic se is adjoined to the verb, signalling the passive character of the subject while blurring the presence of the agent: El libro se publicó el año pasado 'The book was published [lit. published itself] last year' (cf. Mendikoetxea, 1999b). The main difference between both passive constructions seems to be of an aspectual kind: the ser passive is specialized for the encoding of events or transitions (Mendikoetxea, 1999a: 1621), which explains why it is possible only with transitive verbs and usually appears with perfective verbal tenses indicating permanent end states (cf. also Gries \& Stefanowitsch, 2006: 109-110; Noh, 2011). On the other hand, the reflexive passive is much more versatile, being part of the wide array of Spanish structures containing the clitic se. These are all cognitively unified by an internalization of the event inside the clause subject and a reduction of the energy flow between the origin and the endpoint, which tend to identify with each other (García-Miguel, 2003: 74).

The periphrastic construction also gives prominence to the patient subject, but does not so evidently condense the event inside it, which probably explains why it has usually been described as a reformulation of an active clause. Its usage in Spanish is natural only when describing fairly prototypical transitive events such as the one in (10a, b) above. This would seem to make it adequate for informational texts such as news pieces. If the utterance May I suggest to the Mayor that this lady be resigned in (9) above may sound humorous, this is partly due to its lack of an active transitive counterpart: the speaker is suggesting that, since the person in question is not willing to resign by herself, the Mayor should cease her-but still making it look like a personal decision. The rare examples of passives in scarcely transitive contexts usually convey some rhetoric or formulaic tone and, most notably, require an indeterminate agent, such as todos 'everyone' in (12).

(12) Por todos es sabido que el club no atraviesa su mejor situación económica, por lo que la llegada de este delantero serviría para dar por cerrada la plantilla del Salamanca para la próxima temporada. [ $\mathrm{La}$ 
Gaceta, 08/12/04, p. 57]

'It is known by everyone that the club is not in the best of financial situations, so with the acquisition of this forward player the Salamanca soccer team should be set for the upcoming season.'

Table 4. Agent expression vs. omission in ser passive clauses

\begin{tabular}{lcc}
\hline Agent / origin & Passive clauses & $\%$ \\
\hline Expressed & 58 & 31.2 \\
Omitted & 128 & 68.8 \\
\hline Total & 186 & 100 \\
\hline
\end{tabular}

As shown in Table 4, even if the expression of the agent is usually acceptable, it does become explicit in just little more than $30 \%$ of our items. Passive constructions tend to reduce the salience of the agent (Blanco Gómez, 2002), just as they increase that of the patient. The tendency is understandably stronger in reflexive passives, where agent formulation is rare: ?El libro se publicó por otra editorial 'The book was published [lit. published itself] by a different publishing house'. In passive contexts, the focus is on the alterations suffered by the subject; attention is placed on the endpoint rather than the origin of the process. In example (13) it is clear that what matters to the speaker is the damage that might be caused to the subject; at the same time, an intention to silence the agent may be perceived.

(13) hay gente- hay gente mayor / prácticamente toda / que no quiere ser desarraigada de sus domicilios / quieren seguir viviendo donde siempre han vivido / ento(nc)es / m: la política de residencias / tiene / ese límite al fracaso [Cadena Cope, 5/23/03, 12:30]

'There are many elderly people - virtually all of them — who don't want to be uprooted from their homes. They want to remain where they have always lived. So the policy of retirement homes is doomed to failure.'

The preceding discussion makes it possible to undertake a final inquiry into the connections between the discursive value of the passive construction and its sociolinguistic distribution in the media, as analyzed in Section 3.

\subsection{The Projection of Meaningful Choice onto Communicative Context}

The association of the passive with scripted informational genres has already been partly explained: it is an adequate resource for the description of perfective transitive events causing permanent changes in some entity. In this sense, it is worth adding that 185 of 186 passive clauses in the corpus have third-person subjects. Firstand second-person referents tend to dominate spontaneous conversational interactions; passives are understandably more frequent across texts recounting events in which third person-entities are involved. In the corpus, such texts are most often written and highly pre-planned ones. As noted by Finegan and Biber (2001: 262) and Aijón-Oliva (2006: 683ff), not only linguistic variants, but also the discursive contexts favoring their occurrence, are more frequent in some situations than others.

This can also help explain a statistical fact that called our attention as seemingly contradictory: the relatively low frequency of passives in written stories as against news items (see again 3.1). Notwithstanding their many stylistic similarities, stories are different from news texts proper in that the former tend to discuss everyday matters rather than last-minute facts; they are less concerned by what happened to third-person referents than by general aspects of the society in which readers themselves live. In fact, most items of passive clauses in this genre are found across occasional informational or narrative stretches, as happens in (14), reviewing an exhibition on the Spanish Civil War.

(14) una bomba terminó con la vida de su hermana, sólo cuatro años mayor, que fue enterrada con parte de su vestido y con la mitad de su muñeca más querida. [...] Intenso es también el escalofrío que brota durante la lectura de una carta escrita desde la prisión de Santander por José Gómez Miguel a su esposa y su hija. Fue el 10 de enero de 1938, el mismo día en el que fue fusilado [El Adelanto, 04/07/04, p. 53]

'A bomb ended the life of her sister, only four years older, who was buried with the remains of her dress and one half of her favorite doll... Just as spine-chilling is the reading of a letter sent from the Santander prison by J.G.M. to his wife and his daughter. It was January 10th, 1938, the same day he was executed.'

Similarly, radio genres where the description of permanent end states is uncommon — which includes all those 
included in the corpus, except for news reports - are those with the lowest frequencies of passives, as has also been shown.

The potential of passive constructions to blur the salience of semantic agents is also worth consideration. In fact, passivization, together with nominalization, has often been seen by critical linguists and critical discourse analysts (e.g. Fowler et al., 1979; Fairclough, 2003) as a choice intended to hide agency and therefore responsibility. The higher frequencies of passive clauses for some speaker groups may be revealing of ideological interests. Even if it is not our goal to undertake a critical analysis of the passive, some of the examples transcribed across the study could be interpreted in this light. In (15), it is possible to perceive an intention to avoid emphasis on those who would be liable for the failure in meeting the deadline in question:

(15) La Junta ya se había comprometido en las Cortes a resolver las deficiencias del edificio en el 2003, un plazo que ya ha sido superado. [El Adelanto, 1/29/04, p. 16]

'The regional administration had committed itself before the Parliament to fixing the flaws in the building before the end of 2003, a deadline that has already been exceeded.'

Finally, the typical occurrence of the passive across specific types of texts and speakers might be expected to result in its being associated with high social status in speech communities and becoming linked to norms of good usage. ${ }^{\mathrm{x}}$ People who-due to their occupation and general social milieu-participate most assiduously in written informational interactions should be more inclined to using the linguistic constructions associated with them. The higher frequencies of passives in those social groups most often involved in activities of public communication - journalists and broadcasters, as well as politicians and other public figures — could thus have a functional basis that in practice is inseparable from social and ideological considerations.

In sum, the analysis supports the hypothesis that there is an essential connection between the discursive meaning of syntactic constructions and their social and situational distribution. Many authors have suggested that grammatical form varies together with meaning, and that form-meaning amalgams may well be statistically patterned across the social-situational spectrum (Lavandera, 1978; Sankoff, 1988; Eckert, 2008; Hasan, 2009; Terkourafi, 2011, among others). If this fact is approached from a rigorously scientific viewpoint - that is, if ideological interpretations such as those made of Bernstein's (1971) model are avoided-, it can offer a fruitful path towards the theoretical explanation of sociolinguistic patterns (cf. also Aijón-Oliva \& Serrano, 2012).

However, hypotheses like these will need to be much further developed and tested in other grammatical constructions and communicative contexts. This could make it possible to shape a theory of linguistic variation as grounded on discursive and cognitive principles.

\section{Conclusions}

In this paper, the use of the Spanish periphrastic passive has been quantitatively and qualitatively analyzed across a corpus of oral and written media texts. A marked preference for the construction is detected in the most prototypical media genres, that is, pre-planned informational ones. It is also most frequent in the speech and writing of journalists and broadcasters. However, the rest of the socioprofessional groups analyzed also use it as a stylistic resource in certain contexts. Politicians often resort to the construction when intending to invest discourse with high assertiveness; and even the speakers with the lowest rate of the construction-private individuals - sporadically choose it when seeking an elaborate writing style in letters to the editor of a journal.

We have also investigated the possible connections between the social and situational patterning of the ser passive and its discursive meaning. The use of the construction is frequently prompted by the textual progression of informational texts, whereby a semantic patient, originally conceived-and sometimes formulated-as an object, rises to the position of the subject while undergoing a parallel increase in contextual salience. The results of the analysis lend some support to the hypothesis that the functional and cognitive values of this construction are not only at the basis of its particular uses, but also of its social and situational distribution. The transmission of propositional information is most often associated with written, pre-planned discourse, which thus offers greater chances to use passive structures than spontaneous and interpersonal communication. The higher frequency of passives in those socioprofessional groups most accustomed to public communication is probably a reflection of this association.

With the choice of some syntactic-semantic configuration, speakers are able to create meanings at all levels simultaneously, from the descriptive to the social and situational ones, giving rise to the notion of style as the generation of meaning through formal choice. The further development and testing of hypotheses like the ones proposed here may open a path towards the theoretical explanation of the linguistic distributional patterns observed across human languages and communities. 


\section{Acknowledgments}

This paper is part of the research project "Los estilos de comunicación y sus bases cognitivas en el estudio de la variación sintáctica en español", funded by the Spanish Ministerio de Ciencia e Innovación. It has also benefited from a grant by the Fundación "Memoria de D. Samuel Solórzano Barruso" (Universidad de Salamanca). I am grateful to Prof. María José Serrano (Universidad de La Laguna, Spain) as well as two anonymous reviewers for comments and suggestions on earlier versions.

\section{References}

Aijón-Oliva, M. A. (2006). Variación morfosintáctica e interacción social. Salamanca: Ediciones Universidad de Salamanca.

Aijón-Oliva, M. A., \& Serrano, M. J. (2012). Towards a comprehensive view of variation in language: The $\begin{array}{lllll}\text { absolute variable. Language and } & \text { Communication, }\end{array}$ http://dx.doi.org/10.1016/j.langcom.2011.07.001

Auer, P. (Ed). (2007). Style and social identities. Alternative approaches to linguistic heterogeneity. Berlin: Mouton de Gruyter.

Bernstein, B. (1971). Class, codes and control. Vol. 1: Theoretical studies toward a sociology of language. London: Routledge and Kegan Paul. http://dx.doi.org/10.4324/9780203014035

Biber, D. (1988). Variation across speech and writing. Cambridge: Cambridge University Press. http://dx.doi.org/10.1017/CBO9780511621024

Biber, D., \& Conrad, S. (2009). Register, genre, and style. Cambridge: Cambridge University Press. http://dx.doi.org/10.1017/CBO9780511814358

Blanco Gómez, M. L. (2002). Hiding the agent in English and Spanish newspaper articles: The periphrastic passive. In J. Marín Arrese (Ed.), Conceptualization of events in newspaper discourse: Mystification of agency and degree of implication in news reports (pp. 9-30). Madrid: Servicio de Publicaciones de la Universidad Complutense.

Blas Arroyo, J. L. (2011). Variación y discurso: Factores institucionales y estilísticos en la formulación de preguntas en el debate electoral cara a cara. In M. J. Serrano (Ed.), Variación variable (pp. 57-91). Almería: Círculo Rojo/Ministerio de Ciencia e Innovación.

Bucholtz, M., \& Hall, K. (2005). Identity and interaction: A sociocultural linguistic approach. Discourse Studies, 7, 585-614.

Casado Velarde, M. (1995). El lenguaje de los medios de comunicación. In M. Seco \& G. Salvador (Eds.), La lengua española, hoy (pp. 153-164). Madrid: Fundación Juan March.

Casanovas Català, M. (1999). La identidad semántica en la variación sintáctica: Un estudio empírico. In M. J. Serrano (Ed.), Estudios de variación sintáctica (pp. 237-260). Frankfurt am Main: Vervuert / Madrid: Iberoamericana.

Chambers, J. K. (2003). Sociolinguistic theory (2nd ed.). Oxford: Blackwell.

Coupland, N. (2007). Style: Language variation and identity. Cambridge: Cambridge University Press. http://dx.doi.org/10.1017/CBO9780511755064

Croft, W., \& Cruse, D. A. (2004). Cognitive linguistics. Cambridge: Cambridge University Press. http://dx.doi.org/10.1017/CBO9780511803864

Eckert, P. (2008). Variation and the indexical field. Journal of Sociolinguistics, 12, 453-476. http://dx.doi.org/10.1111/j.1467-9841.2008.00374.x

Fairclough, N. (2003). Analyzing discourse. London: Routledge.

Fernández, S. S. (2004). Un análisis funcional de la voz pasiva española. In M. Villayandre Llamazares (Ed.), Actas del V Congreso de Lingüística General (pp. 907-916). Madrid: Arco Libros.

Fernández, S. S. (2007). La voz pasiva en español: Un análisis discursivo. Frankfurt: Peter Lang.

Finegan, E., \& Biber, D. (2001). Register variation and social dialect variation: The Register Axiom. In P. Eckert \& J. R. Rickford (Eds.), Style and sociolinguistic variation (pp. 235-267). Cambridge: Cambridge University Press.

Fowler, R., Hodge, B., Kress, G., \& Trew, T. (1979). Language and social control. London: Routledge. 
Fried, M. (2009). Word order. In F. Brisard, J. O. Östman \& J. Verschueren (Eds.), Grammar, meaning and pragmatics (pp. 289-300). Amsterdam / Philadelphia: John Benjamins.

García, E. C. (2009). The motivated syntax of arbitrary signs: Cognitive constraints on Spanish clitic clustering. Amsterdam / Philadelphia: John Benjamins.

García-Miguel, J. M. (2003). Integración semántica en las construcciones causativas reflexivas del español. In N. Delbecque (Ed.), Aproximaciones cognoscitivo-funcionales al español (pp. 65-82). Amsterdam: Rodopi.

Givón, T. (2001). Syntax: An introduction. Amsterdam / Philadelphia: John Benjamins.

Goldberg, A. E. (1995). Constructions. A construction-grammar approach to argument structure. Chicago: The University of Chicago Press.

Gonzálvez-García, F. (2006). Passives without actives: Evidence from verbless complement clauses in Spanish. Constructions SV1-5/2006. Retrieved from www.constructions-online.de.

Gries, S. T., \& Stefanowitsch, A. (2006). Extending collostructional analysis: A corpus-based perspective on $\begin{array}{lllll}\text { 'alternations'. International Journal of Corpus Linguistics, 9, } & \text { 97-129. }\end{array}$ http://dx.doi.org/10.1075/ijcl.9.1.06gri

Grijelmo, A. (2006). La gramática descomplicada. Madrid: Taurus.

Gundel, J. K., \& T. Fretheim. (2009). Information structure. In F. Brisard, J. O. Östman \& J. Verschueren (Eds.), Grammar, meaning and pragmatics (pp. 146-160). Amsterdam / Philadelphia: John Benjamins.

Hasan, R. (2009). Semantic variation: Meaning in society and sociolinguistics. London: Equinox.

Lambrecht, K. (1994). Information structure and sentence form. Cambridge: Cambridge University Press.

Langacker, R. W. (1991). Foundations of Cognitive Grammar. Vol. II: Descriptive application. Stanford: Stanford University Press.

Langacker, R. W. (2009). Investigations in Cognitive Grammar. Berlin: Mouton de Gruyter. http://dx.doi.org/10.1515/9783110214369

Lavandera, B. R. (1978). Where does the sociolinguistic variable stop? Language in Society, 7, 171-182. http://dx.doi.org/10.1017/S0047404500005510

López Morales, H. (2000). En torno a la variación sintáctica: Activas y pasivas. Datos empíricos. In P. Carbonero Cano (Ed.), Lengua y discurso. Estudios dedicados al profesor Vidal Lamíquiz (pp. 579-585). Madrid: Arco Libros.

López Morales, H. (2006). El estudio de la variación sintáctica: Precisiones metodológicas. In J. L. Blas Arroyo, M. Velando Casanova \& M. Casanova Ávalos (Eds.), Discurso y sociedad: Contribuciones al estudio de la lengua en contexto social (pp. 81-98). Castellón: Universitat Jaume I.

Mendikoetxea, A. (1999a). Construcciones inacusativas y pasivas. In I. Bosque \& V. Demonte (Eds.), Gramática descriptiva de la lengua española (pp. 1575-1629). Madrid: Espasa Calpe.

Mendikoetxea, A. (1999b). Construcciones con se: Medias, pasivas e impersonales. In I. Bosque \& V. Demonte (Eds.), Gramática descriptiva de la lengua española (pp. 1631-1722). Madrid: Espasa Calpe.

Morales, A. (1992). Acerca de la topicalidad de objeto en algunos dialectos del español. Revista de Filología Española, 72, 671-685.

Noh, E. (2011). Distribución de la pasiva del español: análisis sintáctico basándose en un corpus lingüístico. In V. Maurya \& M. Insúa (Eds.), Actas del I Congreso Ibero-asiático de Hispanistas: Siglo de Oro e hispanismo general (pp. 457-470). Pamplona: Universidad de Navarra.

Oliver del Olmo, S. (2004). Análisis contrastivo español/inglés de la atenuación retórica en el discurso médico: el artículo de investigación y el caso clínico. PhD dissertation, Universitat Pompeu Fabra.

Orwell, G. (1946, April). Politics and the English language. Horizon, 13, 252-265.

Preston, D. R. (2001). Style and the psycholinguistics of sociolinguistics: The logical problem of language variation. In P. Eckert \& J. R. Rickford (Eds.), Style and sociolinguistic variation (pp. 279-304). Cambridge: Cambridge University Press.

Pullum, G. K. (2009, April 17). 50 years of stupid grammar advice. The Chronicle of Higher Education: The Chronicle Review, 55. Retrieved from http://chronicle.com/article/50-Years-of-Stupid-Grammar/25497.

Real Academia Española, \& Asociación de Academias de la Lengua. (2009). Nueva gramática de la lengua 
española. Madrid: Espasa-Calpe.

Rodríguez, J. M. (2001). Errores comunes en el lenguaje periodístico: Invasión pasiva. Revista Latinoamericana de Comunicación Chasqui, 76. Retrieved from http://redalyc.uaemex.mx/pdf/160/ 16007609.pdf.

Salazar, D., Ventura, A., \& Verdaguer, I. (2013). A cross-disciplinary analysis of personal and impersonal features in English and Spanish scientific writing. In I. Verdaguer et al. (Eds.): Biomedical English: A corpus-based approach (pp. 121-143). Amsterdam: Benjamins.

Sankoff, D. (1988). Sociolinguistics and syntactic variation. In F. J. Newmeyer (Ed.), Linguistics: The Cambridge survey (vol. IV, pp. 140-161). Cambridge: Cambridge University Press. http://dx.doi.org/10.1017/CBO9780511620577.009

Seco, M. (1996). Gramática esencial del español (4th ed.). Madrid: Espasa Calpe.

Serrano, M. J., \& Aijón-Oliva, M. A. (2011). Syntactic variation and communicative style. Language Sciences, 32, 138-153. http://dx.doi.org/10.1016/j.langsci.2010.08.008

Terkourafi, M. (2011). The pragmatic variable: Toward a procedural interpretation. Language in Society, 40, 343-372. http://dx.doi.org/10.1017/S0047404511000212

Vázquez Laslop, M. E., \& Hernández Díaz, A. (2010). Impersonalidad y pasividad en las normas sobre derechos humanos: el uso de se y de pasivas perifrásticas en las constituciones mexicanas (1824-2001). Revista Internacional de Lingüística Iberoamericana, 8, 203-231.

Vilches Vivancos, F., \& Sarmiento González, R. (2011). Manual de lenguaje jurídico-administrativo. Madrid: Dykinson.

Weiner, E. J., \& Labov, W. (1983). Constraints on the agentless passive. Journal of Linguistics, 19, 29-58. http://dx.doi.org/10.1017/S0022226700007441

\footnotetext{
Notes

${ }^{\mathrm{i}}$ Conversely, it could be argued that some syntactic configurations can only be formulated as passives and not as actives. The latter situation is rare in Spanish, but not so much in English: Mary is rumored to be a Mormon / *They rumor Mary to be a Mormon (cf. Gonzálvez-García, 2006:3). This supports the basic tenet that every construction has a unique meaning.

ii In view of difficulties such as the ones exposed, Weiner and Labov (1983) had to limit their analysis to English agentless passive clauses vs. impersonal active ones; Morales (1992) proceeded similarly with Spanish. However, the exclusion of overt-agent passives is difficult to justify on theoretical grounds.

iii As is known, the English passive also came to be despised by prescriptionists during the 20th century, with Orwell (1946) famously including it among a list of traits to be avoided. The cliché seems to have spread, even if it has also been extensively rebutted (Pullum, 2009; Biber \& Conrad, 2009:122-123).

iv The complete corpus is published as an appendix to Aijón-Oliva (2006).

${ }^{v}$ This can be done by multiplying the number of passive clauses by 10000 and then dividing it between the word number of the factor we're interested in.

${ }^{\text {vi }}$ The statistical analyses were carried out with the aid of the software package IBM SPSS 20.

vii The different sizes of the genres (see Table 1) are aimed to approximately reflect their unequal share of newspaper pages and radio airing time respectively.

${ }^{\text {viii }}$ It is thus intended to overcome the traditional, static consideration of social classes as mere reference points for statistical correlation (Chambers, 2003: §2.2). Group affiliation should rather be understood as a set of contextualized creative strategies for self-presentation (Coupland, 2007: ch. 5).

ix This entails a different perspective from that of classic studies of linguistic variation, which see independent variables as unrelated forces whose influence must be ascertained. This prompts the resorting to multivariate analysis techniques. Such a cause-effect conception of language use neglects the fact that the various facets of meaning do not appear clearly detached from one another in real communication.

${ }^{x}$ Which is not meant to imply that notions like prestige and norm should need to go together. At least in the particular case of the Spanish passive, it seems quite clear that it is social consideration rather than the official linguistic norm that promotes its use. As noted in 1.1, many prescriptionists, though not rejecting the construction as incorrect, disprefer it in favor of the reflexive passive and other more frequent and 'natural' alternatives.
}

\section{$(\mathrm{cc}) \mathrm{BY}$}

This work is licensed under a Creative Commons Attribution 3.0 License. 